\title{
Removal of Chromium (VI) by Bacillus subtilis Isolated from East Calcutta Wetlands, West Bengal, India
}

\author{
Srabanti Basu, Monikankana Dasgupta, and Bhaswati Chakraborty
}

\begin{abstract}
Chromium (VI), one of the major pollutants released from tanneries, dye and textile industries, is highly toxic and carcinogenic in nature. Chemical methods for bulk treatment of industrial effluents often fail to reduce the level to meet the environmental regulations. For end of the pipe treatment, bioremediation is considered a better alternative. East Calcutta Wetlands, the major sewage treatment site of Kolkata (previously known as Calcutta), has been reported to be contaminated with several heavy metals including chromium (VI). Therefore, there is a possibility that bacterial population of this region can tolerate chromium (VI) and would be useful for bioremediation of chromium (VI). A strain of Bacillus subtilis isolated from this region was grown in presence of chromium (VI) $(2.5 \mu \mathrm{g} / \mathrm{L}-7.55 \mu \mathrm{g} / \mathrm{L})$. There were $97 \%$ and $90 \%$ reduction of residual chromium concentration in growth media after 24 hours with initial concentrations of $2.5 \mu \mathrm{g} / \mathrm{L}$ and $5 \mu \mathrm{g} / \mathrm{L}$ respectively. Best removal was observed at $30^{\circ} \mathrm{C}$. Growth of the Bacillus strain in presence of chromium (VI) was found to be best fit for Tessier model by non-linear regression analysis using MATLAB $®$ 7.4. The Bacillus strain has the potential for the end of the pipe treatment removal of chromium (VI).
\end{abstract}

Index Terms-Bioremediation, chromium, East Calcutta Wetlands, kinetic modeling.

\section{INTRODUCTION}

Chromium (VI) is one of the most hazardous pollutants released from industries like textile dyeing, chemicals and pigment production, wood preservation, tanning and electroplating. [1]. Chromium exists in several oxidation states ranging from -2 to +6 , among which chromium (IV) and chromium (III) are the most significant because of their persistence and stability. Chromium (VI) finds its place in the priority list prepared by the Agency of Toxic Substances and Diseases Registry (ATSDR). Chromium compounds can lead to mutation and cancer, and inhibit enzymes and nucleic acid synthesis. In contrast, chromium (III) is less toxic and less mobile [2]. Chemical methods are available for removal of chromium in bulk from industrial effluent but they often fail to meet the environmental regulations. Therefore polishing steps are or end of the pipe treatment is required.

Bioremediation is recommended as a better alternative to chemical treatment for this purpose as the chemical agents add to the environmental pollution. Studies have reported

Manuscript received May 1, 2013; revised September 5, 2013.

Srabanti Basu, Monikankana Dasgupta and Bhaswati Chakraborty are with the Department of Biotechnology, Heritage Institute of Technology, Kolkata 700107, India (e-mail: srabanti_b@yahoo.co.uk, monikankana.dasgupta@gmail.com, bhaswati77@gmail.com). potential of certain species of bacteria like Pseudomonas, Bacillus and Arthrobacter for bioremediation of chromium [3]-[5].

In contaminated sites, chromium availability is influenced by processes like complex formation, oxidation-reduction, precipitation, which in turn depend on microbial activities. However, exposure to chromium for a long time can reduce microbial diversity, population and activity. Many bacterial species surviving in presence of chromium for years in contaminated sites are found to be highly resistant to chromium and are considered important for removal of chromium [6].

East Calcutta Wetlands, the major site for sewage treatment and resource recovery of the metropolitan city Kolkata (previously known as Calcutta), has been found to be contaminated with heavy metals like chromium, lead and mercury [7], [8]. The site receives domestic waste as well as industrial waste, particularly wastes generated by tanneries situated at the outskirts of the city. The Kolkata Municipality generates 600 million L of wastewater which flows through underground sewers to the pumping stations at the eastern fringes of the city and is then pumped into open channels. The wastewater is received by 286 sewage-fed fisheries and local farms for resource recovery. The wetland has been incorporated in the list maintained by the Ramsar Buraeu established under the Ramsar Convention and is recognized as a 'Wetland of International Importance' [9]-[11].

The present study attempts to check the potential of a strain of Bacillus subtilis isolated from East Calcutta Wetlands for bioremediation of chromium (VI). The bacterial strain, initially tested for biodegradation of phenolic compounds, was tested for its efficacy for removal of chromium.

\section{Methods AND MATERIALS}

\section{A. Maintenance of the Bacteria in Laboratory}

The strain of Bacillus subtilis isolated from the soil sample collected from East Calcutta Wetlands was maintained in laboratory in mineral salt agar containing $1 \%$ glucose as the sole carbon source. Composition of the media (for $1 \mathrm{~L}$ ) is $\mathrm{KH}_{2} \mathrm{PO}_{4}: 0.68 \mathrm{~g}, \mathrm{~K}_{2} \mathrm{HPO}_{4}: 1.73 \mathrm{~g}, \mathrm{FeSO}_{4}: 0.03 \mathrm{~g}, \mathrm{NH}_{4} \mathrm{NO}_{3}$ : $0.1 \mathrm{~g}, \mathrm{MgSO}_{4}: 0.10 \mathrm{~g}, \mathrm{CaCl}_{2}: 0.02 \mathrm{~g}, \mathrm{MnSO}_{4}: 0.03 \mathrm{~g}, \mathrm{pH}$ maintained at 7.0. 24-hour old culture grown in mineral broth containing $1 \%$ glucose was used as inoculum for further studies.

\section{B. Assay of Chromium and Determination of Biomass}

Chromium concentration was determined by spectrophotometric analysis using diphenylcarbazide 
following standard protocol prescribed by APHA [12]. The reaction is specific for chromium (VI) and can be applied for estimation of chromium in the $\mu \mathrm{g} / \mathrm{L}$ level. Bacterial biomass was quantified taking absorbance at $600 \mathrm{~nm}$ using spectrophotometer [13].

\section{Preliminary Study for Removal of Chromium}

The bacterial strain was grown in mineral salt broth having glucose as the sole carbon source in presence of chromium at $30^{\circ} \mathrm{C}$. Residual chromium concentration was estimated after 24 hours.

\section{Kinetic Study for Removal of Chromium and Bacterial Growth in Batch Mode}

For kinetic study for removal of chromium, the isolate was grown in mineral salt broth having glucose as the sole carbon source in presence of chromium. Process parameters like volume of inoculum, initial concentration of chromium (VI) and $\mathrm{pH}$ were varied in a prescribed manner. Residual chromium (VI) was estimated at different time intervals. Bacterial growth was measured under the same experimental conditions.

\section{E. Modeling the Kinetics of the Culture Growth in Presence of Chromium}

The model equations for kinetic modeling were solved by non-linear regression method using MATLAB®7.4.

\section{RESUlTS AND DisCUSSION}

The bacterial strain removed $97 \%, 89 \%$ and $55 \%$ chromium (VI) from medium in 24 hours starting with the initial concentration of $2.5 \mathrm{mg} / \mathrm{L}, 5 \mathrm{mg} / \mathrm{L}$ and $7.5 \mathrm{mg} / \mathrm{L}$ respectively (Table 1 ). Percentage removal of chromium (VI) was similar to the observation made by Mahmood et al who reported $100 \%$ removal of chromium (VI) by Pseudomonas putida and Serratia proteamaculans starting with an initial concentration of $2 \mathrm{mg} / \mathrm{L}$. Both the strains were isolated from tannery waste [14]. Results of the present study for chromium removal indicate that the isolate could tolerate chromium (VI) and further studies could be carried out with the isolate for removal of chromium (VI).

TABLE I: REDUCTION IN CHROMIUM (VI) CONCENTRATION IN MEDIA BY THE ISOLATE AFTER 24 HOURS (5\% V/V INOCULUM, $30^{\circ} \mathrm{C}$, PH 7.0, VOLUME

\begin{tabular}{lll}
\multicolumn{3}{c}{ OF MEDIA 20 ML) } \\
\hline \hline $\begin{array}{lll}\text { Initial concentration of } \\
\text { chromium (VI) }(\mathrm{mg} / \mathrm{L})\end{array}$ & $\begin{array}{l}\text { Final concentration of } \\
\text { chromium (VI) (mg / }\end{array}$ & Percent reduction \\
& $\mathrm{L})$ & \\
\hline 2.5 & 0.058 & 97.68 \\
5 & 0.52 & 89.6 \\
7.5 & 3.362 & 55 \\
\hline \hline
\end{tabular}

Less growth of bacteria was observed in 24 hours in presence of chromium (VI) using $5 \%(\mathrm{v} / \mathrm{v})$ inoculum, at $\mathrm{pH} 7$, and $30^{\circ} \mathrm{C}$ (Fig. 1). The lag phase was found to be considerably increased in presence of chromium (VI) since the cells were not initially acclimatized to chromium (VI). However, the change is similar for different concentrations of chromium (VI) ranging from $2.5-7.5 \mathrm{mg} / \mathrm{L}$. Growth rate was also reduced with introduction of larger volume (10\% and $15 \% \mathrm{v} / \mathrm{v}$ ) of inoculum. Growth rate was also inhibited both at $20^{\circ} \mathrm{C}$ and $40^{\circ} \mathrm{C}$ (data not shown).

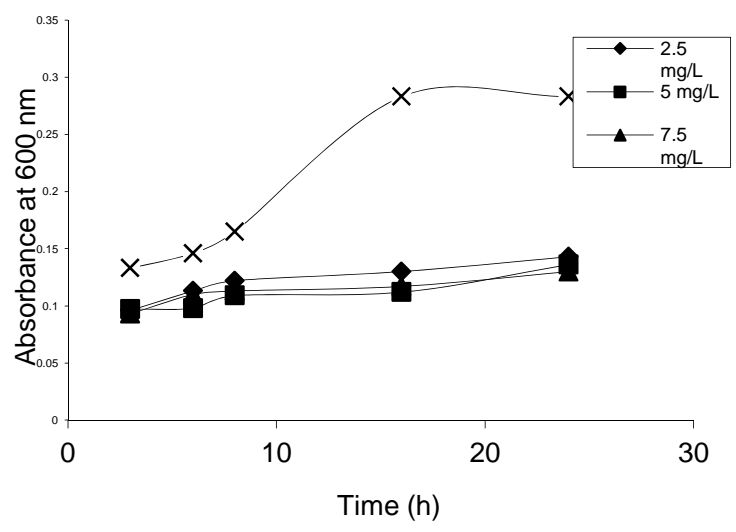

Fig. 1. Growth of bacteria in presence of different initial concentrations of chromium (VI) (5\% v/v inoculum, temperature $30^{\circ} \mathrm{C}, \mathrm{pH} 7.0$, total volume 20 $\mathrm{ml})$.

Percentage removal was decreased with increasing chromium concentration (Fig. 2). This is due to the fact that as the volume of inoculum was constant relatively less biomass was available for chromium (VI) removal from the media, in case of higher concentrations. The result is similar to the observation of Wang and Xiao [15] who reported lower chromium degradation with higher initial concentrations by a Bacillus sp. Isolated by them. DeLeo and Erlich have also reported higher reduction of chromium (VI) for lower initial concentrations by Pseudomonas fluorescence in batch culture. The organisms reduced $61 \%, 69 \%$ and $99.7 \%$ chromium (VI) respectively for initial concentrations of 314, 200 and $112.5 \mathrm{mg} / \mathrm{L}$ [17].

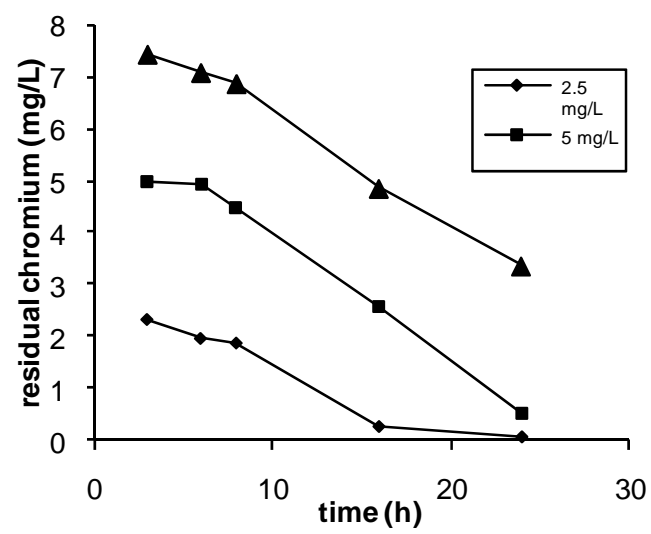

Fig. 2. Removal of chromium from growth media with different initial concentrations ( $5 \% \mathrm{v} / \mathrm{v}$ inoculum, temperature $30^{\circ} \mathrm{C}, \mathrm{pH} 7.0$, total volume 20 $\mathrm{ml})$.

Introduction of larger volume of inoculum in media did not affect removal of chromium (VI) (Fig. 3). Moreover, amount of chromium (VI ) removed from the medium after 24 hours is more with $5 \% \mathrm{v} / \mathrm{v}$ inoculum than with $10 \%$ and $15 \%$ inoculum. This may be due to the fact that higher number of bacterial cells reduces the probability of contact between bacteria cells and chromium. Similar observation was made by another group of researchers who reported higher biotransformation of chromium (VI) to chromium (II) at lower cell density [16]. 


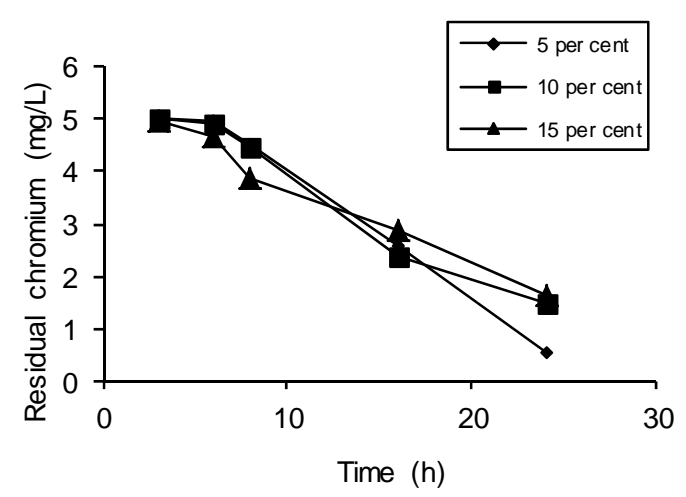

Fig. 3. Removal of chromium from growth media with different inoculum sizes $\left(5 \mathrm{mg} / \mathrm{L}\right.$ initial concentration, temperature $30^{\circ} \mathrm{C}, \mathrm{pH} 7.0$, total volume $20 \mathrm{ml})$.

Chromium (VI) removal by Bacillus subtilis was found to depend on temperature. There was negligible chromium removal at $20^{\circ} \mathrm{C}$. Chromium (VI) removal was maximum at $30^{\circ} \mathrm{C}$. When temperature was increased to $40^{\circ} \mathrm{C}$, chromium (VI) removal was initially increased, but there was insignificant removal after 16 hours. From the results, it may be inferred that adsorption plays a role, at least partly, for removal of chromium. After 16 hours when the biomass is highly loaded with chromium (VI), desorption may take place at higher temperature.

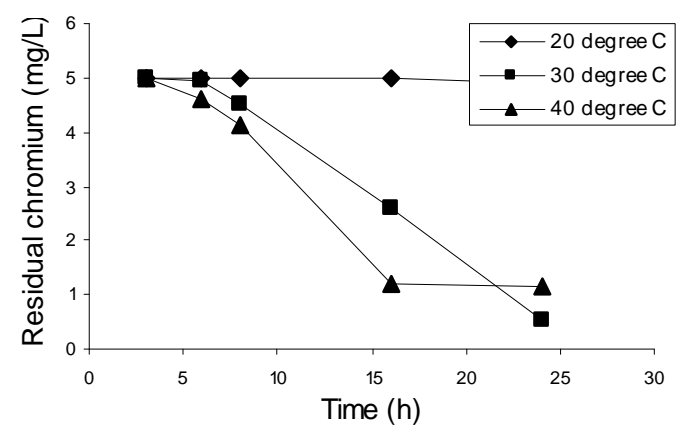

Fig. 4. Removal of chromium from growth media at different temperatures (5 $\mathrm{mg} / \mathrm{L}$ initial concentration, 5\% v/v inoculum size, $\mathrm{pH} 7.0$, total volume 20 $\mathrm{ml})$.

\section{A. Modeling the Kinetics of the Bacterial Growth in Presence of Chromium (VI)}

Different growth models used to describe the growth of microorganisms in absence of substrate inhibition are as follows. The earliest is the Monod model (equation 1) followed by Blackman model (equation 2), Tesssier model (equation 3) and Moser model (equation 4)

$$
\begin{gathered}
\mu=\mu_{m} S /\left(K_{S}+S\right) \\
\mu=\mu_{m} S / 2 K s, \text { if } S<2 K S \\
\mu=\mu_{m}\left(1-e^{-K S}\right) \\
\mu=\mu_{m} S^{n} /\left(K_{S}+S^{n}\right)
\end{gathered}
$$

The experimental values of specific growth rate $\mu$ were plotted against chromium (VI) concentration in the media. The equations were solved by nonlinear regression analysis was using MATLAB ${ }^{\circ}$ 7.4. Fig. 5 showed the fit of these models to the experimental data. From the MATLAB ${ }^{\circledR} 7.4$ analysis, it could be stated that the Tessier model best fitted the experimental data. It showed the least RMSE value of 0.0022574 . The maximum growth rate $\left(\mu_{m}\right)$ values and saturation constant (Ks) values obtained from the kinetic modeling analysis given in Table II. The $\mu_{m}$ and $K s$ values calculated from the Tessier model were $0.026 \mathrm{~h}^{-1}$ and 2.6 $\mathrm{mg} / \mathrm{L}$ respectively.

Activation energy (E) and Arrhenius constant (A) were calculated from Arrhenius equation. Arrhenius equation is given by:

$$
\mu=A e^{-E / R T}
$$

The activation energy for the growth of cells in presence of chromium (VI) was $17467.39 \mathrm{~J} \mathrm{kmole}^{-1}$. Arrhenius constant for the growth reaction is 19.259 .

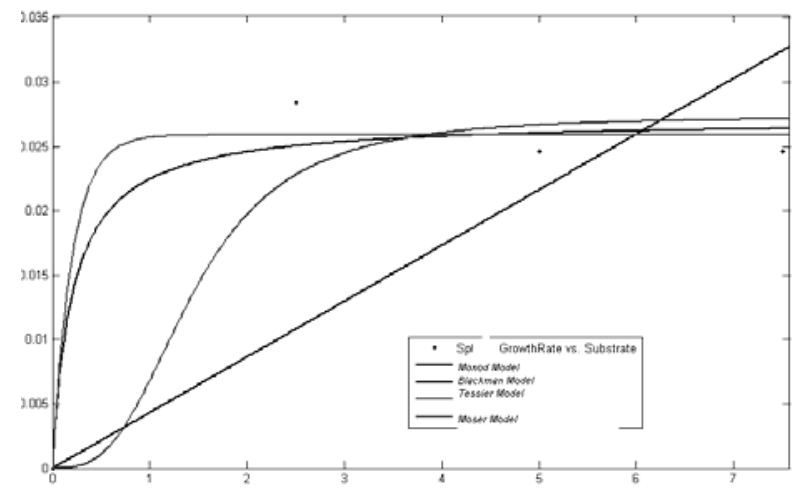

Fig. 4. Kinetic models of the bacterial growth in presence of chromium as solved by MATLAB® 7.4 .

TABLE II: VALUE OF KINETIC PARAMETERS OF THE BACTERIAL GROWTH IN PRESENCE OF CHROMIUM (VI)

\begin{tabular}{lllll}
\multicolumn{5}{c}{ PRESENCE OF CHROMIUM $(\mathrm{VI})$} \\
\hline \hline Monod & $\mu_{\max }\left(\mathrm{h}^{-1}\right)$ & $\mathrm{K}_{2}(\mathrm{mg} / \mathrm{L})$ & $\mathrm{n}$ & RMSE \\
\hline Blackman & 0.02711 & 0.2055 & $\cdots$ & 0.00287 \\
\hline Tessier & 0.0171 & 1.974 & - & 0.01379 \\
Moser & 0.026 & 2.6 & - & 0.00222 \\
\hline \hline
\end{tabular}

\section{CONCLUSION}

The strain of Bacillus subtilis isolated from East Calcutta Wetlands removed chromium from growth medium under laboratory condition. About 90\% removal was observed in 24 hours with initial concentration of $5 \mathrm{mg} / \mathrm{L}$. The strain, which was found to degrade phenolic compounds in previous studies, has a potential for end of the pipe treatment of industrial waste for removal of chromium.

\section{REFERENCES}

[1] A. Agarwal, V. Kumar, and B. D. Pandey, "Remediation options for treatment of electroplating and leather tanning effluent containing chromium - a review," Miner. Process and Extr. Metall., vol. 27, pp. 99-130, 2006.

[2] M. K. Chaturvedi, "Studies on chromate removal by chromium resistant Bacillus sp. Isolated from tannery waste,” J. Environ. Prot., vol. 2, pp. 76-82, 2011.

[3] L. Malachowski, J. L. Stair, and J. A. Holocombe, "Immobilized peptides/ amino acids on solid supports for metal remediation,” Pure Appl. Chem., vol. 76, pp. 777-787, 2004. 
[4] M. Rajkumar, R. Nagendran, K. J. Lee, and W. H. Lee, "Characterization of a novel $\mathrm{Cr}^{6+}$ reducing Pseudomonas sp with plant growth-promoting potential," Curr. Microbiol., vol. 50, pp. 266-271, 2005.

[5] M. Megharaj, S. Avudainayagam, and R. Naidu, "Toxicity of hexavalent chromium and its reduction by bacteria isolated from soil contaminated with tannery waste," Curr. Microbiol., vol. 47, pp. 51-54, 2003.

[6] H. A. Pinon-Castillo, E. M., Brito, M. Goñi-Urriza, R. Guyoneaud, R. Duran, G. V., Nevarez-Moorilon, J. F. Gutierrez-Corona, C. A. Caretta, and G. E. Reyana Lopez, "Hexavalent chromium reduction by bacterial consortia and pure strains from an alkaline industry effluent," J. Appl. Mictobiol., vol. 109, pp. 2173-2182, 2010.

[7] S. raychaudhuri, M. Mishra, M. Sudarshan, and A. R. Thakur, "Traditional aquaculture practice at East Calcutta Wetland: The safety assessment," Am. J. Environ. Sci., vol. 4, pp. 140-144, 2008.

[8] S. Bhattacharyya, P. Chaudhuri, S. Dutta, and S. C. Santra, "Assessment of total mercury level in fish collected from East Calcutta Wetlands and Titagarh sewage fed aquaculture in West Bengal, India," Bull. Environ. Contam. Toxicol., vol. 84, pp. 618-622, 2010.

[9] S. Raychaudhuri, M. Mishra, P. Nandy, and A. R. Thakur, "Waste management: A case study of ongoing traditional practices at East Calcutta Wetland," Am. J. Agri. Biol. Sci., vol. 3, pp. 315-320, 2008.

[10] N. Kundu, M. Pal, and S. Saha, "East Kolkata Wetlands: A resource recovery system through productive activities," in Proc. Taal 2007: The $12^{\text {th }}$ World Lake Conference, India, 2008, pp. 868-881.

[11] D. Ghosh, "Wastewater utilization in East Calcutta Wetlands," Waste, Urban Waste Expertise Programme, Gouda, The Netherlands, occasional paper, 1999.

[12] APHA, AWWA, and AEF, Standard methods for the examination of water and wastewaters, USA, American Public Health Association, 1998.

[13] S. Congeevaram, S. Dhanarani, J. Park, M. Dexilin, and K. Thamaraiselvi, "Biosorption of chromium and nickel by heavy metal resistant fungal and bacterial isolates," J. Haz. Mat., vol. 146, pp. 270-277, 2007.

[14] S. Mahmood, A. Khalid, T. Mahmood, M. Arshad, and R. Ahmad, "Potential of newly isolated bacterial strains for simultaneous removal of hexavalent chromium and reactive black-5 azo dye from tannery effluent," J. Chem. Technol. Biotechnol., vol. 88, pp. 480-487, 2013.
[15] Y. T. Wang and C. Xiao, "Factors affecting hexavalent chromium reduction in pure cultures of bacteria," Water Res., vol. 29, pp. 2467-2474, 1995.

[16] L. Philip, L. Iyengar, and C. Vencobachar, "Cr (VI) redcution by Bacillus coagulans isolated from contaminated soils," J. Enviorn. Engg, vol. 124, pp. 1165-1170, 1998.

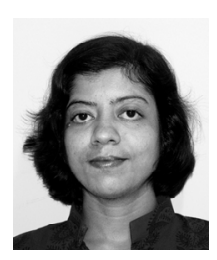

Srabanti Basu was born in Kolkata in 1970. She did M. Sc. and $\mathrm{Ph}$. D. from the University of Calcutta, Kolkata, India, in biochemistry. After receiving $\mathrm{Ph} . \mathrm{D}$. degree, she started her career as a science journalist in The Telegraph, a Kolkata-based daily. She joined the Heritage Institute of Technology as a Lecturer in biotechnology in 2003. Presently she is an Associate Professor in the same department and in the same institute. She has 15 publications in reputed journals. She contributed two chapters in the book titled Recycle and reuse of materials and their products published by Apple Academic Press, New York. Her area of research interest is environmental biotechnology. She received Fulbright Scholarship for Fulbright Nehru Environmental Leadership Program in 2009 and worked as a Visiting Scholar at the New Jersey Institute of Technology.

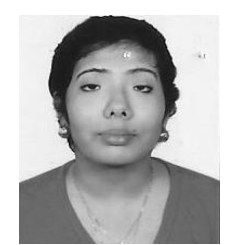

Monikankana Dasgupta was born in Kolkata. She passed B. Tech. in biotechnology from the Haldia Instiute of Technology under the ageis of West Bengal University of Technology (WBUT). She completed M. Tech. from the Heritage Institute of Technology, Kolkata, affliated to WBUT in 2013. biotechnology. She carried out her dissertation on environmental

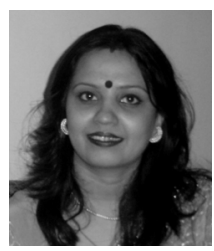

Bhaswati Chakraborty was born in Kolkata in 1977 She did M. Tech. in biotechnology from Anna University, Chennai, India. Presently she is an Assistant Professor in the department of Biotechnology, Heritage Institute of Technology, Kolkata. She worked as a Lecturer and Senior Lecturer in the SRM University, Chennai, DY Patil University, Mumbai, and Birla Institute of Technology, Mesra. She is registered for Ph.D. work in the Jadavpur University, Kolkata. Her area of research interest is bioprocess engineering and environmental biotechnology. 